University of Nebraska - Lincoln

DigitalCommons@University of Nebraska - Lincoln

$1-2011$

\title{
Oral Self Critique: Raising Student Consciousness of Communication (In)Competence
}

\author{
Kristen Lucas \\ University of Nebraska-Lincoln, kristen.lucas@louisville.edu
}

Follow this and additional works at: https://digitalcommons.unl.edu/commstudiespapers

Part of the Communication Commons

Lucas, Kristen, "Oral Self Critique: Raising Student Consciousness of Communication (In)Competence" (2011). Papers in Communication Studies. 19.

https://digitalcommons.unl.edu/commstudiespapers/19

This Article is brought to you for free and open access by the Communication Studies, Department of at DigitalCommons@University of Nebraska - Lincoln. It has been accepted for inclusion in Papers in Communication Studies by an authorized administrator of DigitalCommons@University of Nebraska - Lincoln. 


\title{
Oral Self Critique: Raising Student Consciousness of Communication (In)Competence
}

\author{
Kristen Lucas \\ University of Nebraska-Lincoln, Department of Communication Studies \\ 436 Oldfather Hall, Lincoln, Nebraska 68588-0329, USA \\ Email klucas3@unl.edu
}

Courses: Public Speaking, Business and Professional Communication, Interviewing, or any other skills-based oral communication course

Objectives: Students will become more conscious of their verbal communication patterns, and improve problematic verbal communication disfluencies

\section{Rationale}

Picture this: a graduating senior excitedly tells you about the terrific interview he or she had at the job fair that morning: "At first I was really nervous and I was like there's no way I'm going to get this job. But then the interviewer was like, 'What makes you uniquely qualified for this position?' I was like so relieved to get a question I could answer. So I go, 'Well, I'm like a really good communicator. I've taken like 18 credit hours in upper-division communication studies classes ..." Anyone who has spent time talking to today's college students knows that this conversation is not much of an exaggeration, if it is an exaggeration at all. Unfortunately, problematic verbal communication patterns - including "you know," " uhhh," and the ubiquitous "like" - detract from the credibility of our talented students.

Communication teachers spend considerable time instructing students how to organize and deliver professional oral presentations, design effective PowerPoint slides, answer interview questions, and communicate effectively in problem-solving teams. Yet considerably less time is spent systematically teaching them the communication skill they will use most: day-to-day verbal communication. Improving verbal communication competence will contribute to students' success across a variety of communication contexts (Worley, Worley, \& Soldner, 2008). Therefore, the primary purpose of this activity is to raise students' consciousness of their own ver- 
bal communication patterns and give them a starting point for improving their verbal skills.

\section{The Activity}

The oral self-critique activity proceeds through three parts: (a) an in-class recording, (b) a written assignment, and (c) the posting of digital files to a course management site (e.g., Blackboard, WebCT). This activity is most effective when used near the beginning of a semester so students can benefit from what they learned throughout the semester.

On the day of the in-class recording ask students to form small groups. Distribute a recorder to each group and ask each of them to share a short story (3-4 minutes) about a bad communication encounter they experienced (e.g., bad customer service, a problem with a landlord). Generally, "business" problems are a better choice than interpersonal problems to prevent overdisclosure of personal information. Each group records all of its members' stories.

After all students have had their turn to share and record their story, collect the recorders, and introduce the follow-up written assignment. (Complete written instructions can be distributed in class or posted to an electronic course management site.) Explain that verbal disfluencies can be a strike against credibility and critiquing their own oral skills can help them to improve. Ask students to, first, transcribe their recorded story. Tell them that the transcription should reflect exactly what they have said, including "like every umm and tangent, like, you know." The more accurate the transcription is the better they will be able to analyze their disfluencies. Also remind them that transcription is a time-consuming process and, even though their stories are only a few minutes long, it may take as long as an hour to transcribe.

Second, ask students to examine the speech patterns they see in their transcript and write a one-page reflection. Some guiding questions might include: Are there particular disfluencies, fillers, or expressions that you use too much? Do you go off on tangents? Do you not complete your thoughts? Do you talk too fast? Do you sound as intelligent and articulate as you would like?

Third, ask students to choose one poor speaking habit they identified and make a concerted effort over the next few days to change it. Share some specific tips for tackling the problem. For example, if they decide that they want to work on saying "you know" less, they should pay careful attention and try to catch themselves every time they say it. If they can catch themselves right before they say it, they should pause and focus on saying the next part of their thought without the filler. If they do say it, they should repeat a corrected version of the sentence. They also may want to let their friends and family know their intentions and get them involved in the process by pointing out when they slip. After a few days of working on their targeted disfluency, they should write a two-page detailed analysis of their improvement effort. You may offer the following questions as a guide: Why did you choose the habit you did? When and how long did you pay attention to changing it? Did you ask anyone to help you? How many times did you catch yourself? What did you do when you 
caught yourself? Do you think it helped? What is easiest and most difficult about this task? Emphasize that the point of the assignment is critical reflection, not success per se. Therefore, they can still get a good grade even if they feel that they failed in their improvement efforts. These two-page analyses should be due about one week after making the initial recording.

Finally, upload the digital audio files to the course management site. That way, students can have access to their recordings to complete their transcription and analysis, they can go back to the recording later in the semester to evaluate improvement, and classmates can do peer critiques, as well.

\section{Debrief}

Once students submit the written assignment, ask them to share their perceptions about it. What disfluencies did they have? How did it make them sound? How did they attempt to fix their behavior? How successful were they? Be prepared for an animated class discussion with a lot of laughter and empathy shared by struggling students. You should follow-up the discussion with a mini-lecture on the role of consciousness in developing communication competence. For example, Sprague, Stuart, and Bodary (2010) describe proficiency as developing through four stages: unconscious incompetence, conscious incompetence, conscious competence, and finally unconscious competence. Explain that before doing this activity, they were in the stage of unconscious incompetence. That is, they were unaware of the mistakes they are making. But now they are in the state of conscious incompetence. It may feel uncomfortable realizing how many times they make mistakes, but reassure them that this is a necessary stage to go through before reaching competence levels.

\section{Variation}

You might ask the class to vote on the worst verbal communication habit. The "winning" disfluency can be targeted by the entire class for a shared improvement goal. For example, if the winner is the overuse of "like," students could be encouraged to provide constructive corrections to one another throughout the term. The chosen disfluency also can be targeted in instructor feedback on speeches, interviews, and other oral communication-based assignments.

\section{Appraisal}

Logistically, this can be a challenging activity. However, typical results make it well worth the effort. Actually seeing the number of times they say "like," "you know," or "uhhh" in their transcripts gives students an eye-opening perspective on how they sound to others - a perspective that cannot be gained simply by listening. Of the more than 600 students who have completed this assignment, all have been able to identify at least one problematic disfluency. Students' general consensus is that they are genuinely shocked and deeply embarrassed by their disfluencies, as they do not sound nearly as intelligent and articulate as they believe themselves to 
be. Granted, this activity is not designed to detect all disfluencies in students' talk, nor is it reasonable to expect that they will reach the level of unconscious competence (Sprague et al., 2010) by the end of the course. However, each step towards improvement is an important one that reflects well on students and communication teachers alike.

\section{References and Suggested Readings}

Almeida, E. P. (2004). A discourse analysis of student perceptions of their communication competence. Communication Education, 53, 357-364.

Canary, D. J., \& MacGregor, I. M. (2008). Differences that make a difference in assessing student communication competence. Communication Education, 57, 41-63.

Sprague, J., Stuart, D., \& Bodary, D. (2010). The speaker's handbook. Boston, MA: Wadsworth Cengage Learning.

Worley, D., Worley, D., \& Soldner, L. (2008). Communication counts: Getting it right in college and in life. Boston, MA: Allyn and Bacon. 